\title{
IDENTIFIKASI ADANYA BAKTERI ESCHERICHIA COLI PADA MINUMAN ES TEH YANG DIJUAL DISEKITAR STIKES BCM PANGKALAN BUN WILAYAH KOTAWARINGIN BARAT
}

\author{
${ }^{1}$ Risa Wahyuningsih \\ ${ }^{1}$ Stikes Borneo Cendekia Medika Pangkalan Bun \\ ${ }^{1}$ Email : risa.analisbcm16@yahoo.co.id
}

\begin{abstract}
ABSTRAK
Teh merupakan salah satu minuman yang sangat digemari di Indonesia, disamping harganya yang murah teh merupakan minuman dengan rasa yang cukup enak. Salah satu olahan minuman yang terbuat dari teh yang sangat digemari adalah dalam bentuk dingin. Es teh dibuat dengan cara menyeduh tanaman teh yang sudah di olah dan dikeringkan. Tanaman Teh mempunyai nama latin Camelia Sinensis yang diambil pada bagian tunas daun atau pucuk kemudian diolah dan dikeringkan sebagai produk pembuatan minuman es teh dengan harga yang cukup terjangkau membuat minuman es teh diolah oleh produsen dengan cara yang kurang baik (higienis) ada beberapa kasus terjadinya diare setelah mengkonsumsi es teh. Penelitian ini bertujuan untuk mengetahui ada atau tidaknya bakteri Escherichia coli pada minuman es teh yang dijual di sekitar Stikes Borneo Cendekia Medika dan mengetahui jumlah Escherichia coli dengan metode MPN. Hasil identifikasi jumlah bakteri Escherichia coli pada minuman es teh yang dijual di STIKES Borneo Cendekia Medika Pangkalan Bun didapatkan hasil semua minuman tidak layak konsumsi dengan persentase 100\%. Dari hasil penelitian yang dilakukan dapat disimpulkan bahwa minuman es teh yang dijual di sekitar kampus STIKES Borneo Cendekia Medika Pangkalan Bun didapatkan hasil 10 sampel positif terkontaminasi bakteri Escherichia coli dengan indeks MPN 25$1800 \mathrm{sel} / 100 \mathrm{ml}$.
\end{abstract}

Kata Kunci : Camelia sinensis, Escherichia coli, metode MPN, higienis

\section{IDENTIFICATION ESCHERICHIA COLI BACTERIA IN ICE TEA AROUND STIKES BCM PANGKALAN BUN KOTAWARINGIN BARAT}

\section{ABSTRACT}

Tea is one of the most popular drinks in Indonesia, besides its cheap price, tea is a drink with good taste. One processed beverage made from tea that is very popular is 
in the cold form. Iced tea is made by brewing tea plants that have been processed and dried. The tea plant has the Latin name Camelia Sinensis which is taken on the buds of leaves or shoots and then processed and dried as a product for making iced tea drinks at a price that is quite affordable, making iced tea drinks processed by the manufacturer in an unfavorable (hygienic) manner. after consuming iced tea. This study aims to determine the presence or absence of Escherichia coli bacteria in iced tea drinks that are sold around the Stikes Borneo Scholar Medika and to find out the number of Escherichia coli by the MPN method. The results of the identification of the number of Escherichia coli bacteria in iced tea drinks sold at STIKES Borneo Scholar Medika Pangkalan Bun showed that all drinks were unfit for consumption with a percentage of $100 \%$. From the results of research conducted it can be concluded that the iced tea drinks sold around the campus of STIKES Borneo Scholar Medika Pangkalan Bun obtained 10 positive samples contaminated with Escherichia coli bacteria with an MPN index of 25-1800 cells / 100ml.

Keywords: Camelia sinensis, Escherichia coli, MPN Methods, hygienic

\section{PENDAHULUAN}

Escherichia coli merupakan bakteri batang gram negatif, tidak berspora, motil berbentuk flagel peritrik, berdiameter $\pm 1,1-1,5 \mu \mathrm{m} \mathrm{x}$ $0,2-0,6 \mu \mathrm{m}$. E. coli dapat bertahan hidup dimedium sederhana menghasilkan gas dan asam dari glukosa dan memfermentasi laktosa. Pergerakan bakteri ini motil, tidak motil dan peritrikus, ada yang bersifat aerobik dan anaerobik fakultatif (Elfidasari et al, 2011).

Bakteri E. coli adalah satu jenis spesies utama bakteri gram negatif fakultatif anaerobic yang mempunyai alat gerak berupa flagel dan tersusun dari sub unit protein yang disebut flagelin, yang mempunyai berat molekul rendah dengan ukuran diameter 12-18 $\mathrm{nm}$ dan dengan panjang $12 \mathrm{~nm}$, kaku dan berdiameter lebih kecil dan tersusun dari protein, pili dapat berfungsi sebagai jalan pemindahan DNA saat konjugasi. Selain itu, mempunyai kapsul atau lapisan lendir yang merupakan polisakarida tebal dan air yang melapisi permukaan luar sel (Ikmalia, 2008).

Bakteri E. coli adalah salah satu bakteri yag digunakan sebagai indikator adanya kontaminasi feces dan kondisi sanitasi yang tidak baik terhadap air, makanan, dan minuman. E. coli menjadi patogen jika jumlah bakteri dalam saluran pencernaan meningkat atau berada di luar usus, menghasilkan enterotoksin sehingga menyebabkan terjadinya bebarapa infeksi yang 
berasosiasi dengan enteropatogenik kemudian menghasilkan enterotoksin pada sel epitel. Manifestasi klinik infeksi oleh E. coli bergantung pada tempat infeksi dan tidak dapat dibedakan dengan gejala infeksi yang disebabkan oleh bakteri lain (Ismail, 2012).

a. Enterotoksigenik E. coli (ETEC)

Enterotoksigenik merupakan penyebab paling umum dari diare pada wisatawan (Travellers Diarrhea) dan diare pada bayi di negara berkembang. Ada dua macam eksotoksin yang dihasilkan dari E. coli yaitu: (1) Limfotoksin dikeluarkan bawah kendali genetik plasmid. (2) Sitotoksin yang berada di bawah kendali kelompok plasmid heterogen. Strain yang menghasilkan kedua toksin tersebut menyebabkan diare yang lebih berat (Brooks et al., 2008).

b. Enteroinvasif E. coli (EIEC)

Menyebabkan penyakit yang mirip dengan shigellosis. Sering terjadi pada anak - anak di negara berkembang dan wisatawan yang menuju negara tersebut. EIEC menimbulkan penyakit melalui invasinya ke sel epitel mukosa usus (Brooks et al., 2008).

c. Enteropatogenik E. coli (EPEC)
Enteropatogenik mengacu pada serotipe E. coli tertentu yang pertama dicurigai dalam studi epidemiologi pada 1940-an dan 1950-an sebagai penyebab epidemi dan sporadis diare pada anakanak (Frankel G. et al, 2002).

d. Enterohemoragik E. coli (EHEC)

Sedangkan EHEC dianggap sebagai patogen zoonosis baru yang dapat menyebabkan gastroenteritis akut dan hemoragik kolitis dengan komplikasi ginjal dan neurologis sebagai akibat dari translokasi toksin (Stx 1 dan Stx 2) di usus. Merupakan penyebab utama kematian bayi dalam Negara berkembang (Jawetz et al., 2008)

e. Enteroagregatif E. coli (EAEC)

Akibat infeksinya menyebabkan diare akut dan kronik pada negara berkembang. Bakteri ini ditandai dengan pola khas perlekatannya pada sel manusia. EAEC memproduksi hemolisin dan ST enterotoksin yang sama dengan ETEC (Brooks et al., 2008).

Air merupakan materi yang sangat penting dalam kehidupan, baik tanaman, hewan maupun manusia. Manusia tentu tidak terlepas kehidupannya dari kebutuhan akan air bersih terutama untuk minum. Benda 
cair yang disebut air dapat dibedakan berdasarkan tempatnya, yaitu berasal dari permukaan tanah (air permukaan) dan di dalam tanah (air tanah). Air hujan yang jatuh di tanah sebagian meresap kedalam tanah dan sebagian lain dapat menggenang di permukaan, hal ini bergantung kepada kondisi tanah. Zat air yang diperoleh untuk memenuhi kebutuhan sehari-hari dari hujan, waduk, kubangan, atau sungai, sumber mata air dan sumur. Cairan ini merupakan zat yang mutlak bagi setiap makhluk hidup, dan kebersihannya adalah syarat utama bagi terjaminnya kesehatan. Air merupakan kebutuhan mutlak untuk kehidupan manusia. Cairan ini di dalamnya terdapat berbagai macam zat yang dibutuhkan dan dilain pihak dalam air jugaterdapat berbagai macam hal membahayakan bagi manusia.

Kualitas air, khususnya untuk minum atau memasak akan dapat berakibat pada kesehatan manusia yang mengonsumsinya. Zat ini dibutuhkan manusia dalam segala aspek kehidupan, seperti untuk memasak, mandi, mencuci dan kebutuhan lainnya. Air secara biologis berperan dalam semua proses dalam tubuh manusia, misalnya pencernaan, metabolisme, transportasi, mengatur keseimbangan suhu tubuh. Kekurangan air akan menyebabkan gangguan fisiologis, bahkan akan mengakibatkan kematian, apabila kekurangan tersebut mencapai $15 \%$ dari berat tubuh. Cairan ini apabila tidak jernih misalnya tercemar bahan organik, air akan menjadi media yang baik bagi kuman penyakit. Sumber air yang tercemar bahan kimia organik akan menyebabkan gangguan fisiologis secara menahun bahkan bersifat toksik. Air yang jatuh dari langit membawa serta mikroorganismemikroorganisme yang senantiasa berhamburan di udara, terlebih pada tanah yang berdebu. Di tanah, air menjadi lebih cemar lagi karena sisasisa makhluk hidup (sampah), kotoran dari hewan maupun manusia, dan limbah dari pabrik. Zat air yang mengandung mikroorganisme itu disebut air terkontaminasi, jadi cairan itu tidak steril. Penyakit menular beberapa diantaranya dapat sewaktuwaktu meluas menjadi wabah (epidemi) karena peranan air yang tercemar.

Tubuh manusia sekitar tiga per empat bagiannya terdiri dari air, menjadikannya sebagai zat terpenting untuk kebutuhan dasar berlangsunya kehidupan. Air selain bermanfaat bagi 
manusia, juga merupakan media yang baik untuk kehidupan bakteri. Bakteri ini dibedakan menjadi dua, yaitu bakteri patogen dan non-patogen. Bakteri Patogen dapat menyebabkan penyakit dengan keluhan diare seperti disentri, tipus dan kolera, melalui air yang diminum. Minuman yang aman untuk diminum adalah air bersih yang harus memenuhi persyaratan seperti fisika, kimia, radioaktif daan mikrobiologi yang telah ditetapkan oleh pemerintah. Syarat air bersih secara Mikrobiologi, salah satunya yang dapat dikonsumsi adalah tidak ditemukannya adalah $E$. coli dalam $100 \mathrm{ml}$. Air memiliki masalah utama yang harus dihadapi dalam pengolahannya adalah semakin tingginya tingkat pencemaran, baik pencemaran yang berasal dari air limbah rumah tangga maupun limbah industri. Upaya-upaya baru terus dilakukan untuk mendapatkan sumber air, khususnya untuk pemenuhan akan air minum yang memenuhi persyaratanpersyaratan yang telah ditetapkan.

"Standar air minum di indonesia mengikuti standar WHO yang dalam beberapa hal disesuaikan dengan kondisi di Indonesia. Pada Tahun 2002, Departemen Kesehatan RI telah menetapkan kriteria kualitas air secara mikrobiologis, melalui Keputusan Menteri Kesehatan No.907 tahun 2002 bahwa air minum tidak diperbolehkan menandung bakteri Coliform dan Escherichia Coli. Sedangkan dalam Standar Nasional Indonesia (SNI) N0.01-3553-2006, air minum dalam kemasan selain tidak boleh mengandung bakteri patogen yaitu Salmonela dan Pseudomonas aeruginosa, juga tidak boleh mengandung cemaran mikroba lebih besar dari 100 koloni / ml."16“

Es batu merupakan produk pangan yang sudah sangat dikenal masyarakat secara umum dianggap aman untuk dikonsumsi. Es ini pada masyarakat, dikenal sebagai air yang dibekukan. Pembekuan ini terjadi bila air didinginkan di bawahsuhu $00 \mathrm{C}$, sehingga menjadi massa yang padat dan berbentuk seperti kristal. Massa yang padat terbentuk dikarenakan salah satu molekul air yaitu hidrogen akan bergerak lambat pada suhu $00 \mathrm{C}$, sehingga molekul hidrogen yang satu tidak mampu memutuskan ikatannya dengan lainnya. Ikatan antar molekul hidrogen kerapatannya mengakibatkan air berubah wujud menjadi padat, dan karena zat ini 
berwarna jernih sehingga gambaran warnanya seperti kristal.

Es ini memiliki berbagai macam manfaat, salah satunya yaitu sebagai pelengkap yang disajikan bersamaan dengan air minum, oleh sebab itu es batu termasuk jenis produk pangan pelengkap. Es batu yang ditambahkan pada minuman bertujuan untuk menimbulkan sensasi dingin dan segar, hal tersebut berhubungan dengan suhu di Indonesia yang tropis. Es jenis ini bahkan seringkali digunakan sebagai bahan yang dapat mempertahankan kesegaran atau memperpanjang umur simpan suatu produk pangan. Air yang dibekukan memiliki suhu rendah, semua reaksi metabolisme pada mikroorganisme dikatalisis oleh enzim, dan kecepatan reaksi katalis enzim tersebut sangat dipengaruhi oleh temperature.23 Reaksi metabolisme mikroba yang turun ini menyebabkan es batu dianggap relatif aman, tetapi pada beberapa penelitian terdahulu masih terdapat bakteri patogen yang beredar di pasaran.

Air yang digunakan dalam pembuatan es batu haruslah yang higienis dan memenuhi standar sanitasi. Usaha es batu sekarang masih dalam skala kecil sehingga sampai saat ini, belum ada peraturan pemberian izin atau rekomendasi kelayakan yang baku ditinjau dari segi higienis dan sanitasi. Bakteri pencemar ini keberadaannya menyebabkan rendahnya kualitas es batu yang mungkin berasal dari berbagai hal seperti: bahan baku (air) dan alat-alat yang digunakan dalam proses pembuatannya.

Es yang berasal dari air yang dibekukan dalam refrigerator merupakan bahan pendingin yang biasanya dicampurkan pada minuman, biasanya untuk memberikan rasa segar. Es batu biasanya ditemukan di setiap tempat yang menjual minuman, dari restoran ternama sampai warung pinggir jalan. Es batu yang digunakan untuk membuat minuman biasa menggunakan air yang sebelumnya direbus terlebih dahulu sebelum dibekukan, tetapi ada juga pedagang nakal yang menggunakan bahan dari air mentah untuk mengurangi biaya produksi. Es yang terbuat dari air mentah berwarna putih karena masih banyak gas yang terperangkap di dalamnya. Es yang dibuat dari air mentah biasanya adalah es balok. Es ini jelas-jelas tidak baik dikonsumsi, terlebih lagi jika airnya diambil dari sungai yang tercemar. Es 
dari air matang akan terihat bening karena gas di dalam air terlepaskan ketika proses perebusan. Es seperti ini biasanya disebut es kristal. Es ini biasa juga disebut sebagai es batu bolong karena berbentuk seperti pipa dan bolong di tengahnya.

\section{A. Identifikasi Bakteri Escherichia coli}

Identifikasi bakteri $E$ coli dilakukan dengan tiga tahapan, yaitu uji penduga, uji penegas, dan uji pelengkap.

1. Uji Penduga (Presumtive test) Sampel air diletakkan dalam tabung steril yang berisi Lactose Broth. Beberapa tabung diinkubasi selama 48 jam pada suhu $35^{\circ} \mathrm{C}$, kemudian diperiksa terbentuknya gas, karena bakteri akan memfermentasikan laktosa dan menghasilkan gas. Jika gas tidak terbentuk dalam 24 jam, inkubasi diteruskan hingga 48 jam. Tes penduga dikatakan positif jika pada tabung terdapat gas yang ditandai dengan terapungnya tabung durham. Uji ini mendeteksi sifat fermentative coliform dalam sampel dan harus dikonfirmasi dengan tes konfirmatif untuk menyingkirkan keberadaan organisme lain yang memberikan hasil positif pada fermentasi laktosa.

2. Uji Penegas (Confirmed test) Tabung positif yang didapatkan dari uji penduga dilanjutkan dengan uji penegas. Sampel positif yang menunjukkan gas diinokulasi pada media Brilian Green Lactose Broth, kemudian inkubasi pada suhu $37^{\circ} \mathrm{C}$ selama 48 jam. Apabila dihasilkan gas, maka uji penegas ini dinyatakan positif (Willey, 2008).

3. Uji Pelengkap (Complete test)

Uji pelengkap dilakukan dengan menginokulasikan koloni bakteri pada medium agar dengan cara digoreskan dan diinkubasi selama 24 jam pada suhu $35^{\circ} \mathrm{C}$. agar yang digunakan adalah endo agar dan Eosin Metil Blue (EMB). Pembenihan pada media agar ini mengakibatkan media agar menjadi bewarna ungu tua dengan kemilau tembaga metalik dan membentuk koloni dengan pusat gelap (Willey, 2008).

Minuman Es Teh merupakan salah satu minuman yang sangat digemari di Indonesia, disamping harganya yang murah es teh merupakan minuman dengan rasa 
yang cukup enak. Es teh dibuat dengan cara menyeduh tanaman teh yang sudah di olah dan dikeringkan. Tanaman Teh mempunyai nama latin Camelia Sinensis yang diambil pada bagian tunas daun atau pucuk kemudian diolah dan dikeringkan sebagai produk pembuatan minuman es teh. Tanaman Teh berasal daerah sub tropis yaitu negara Cina, akan tetapi setelah dilakukan beberapa penelitian dan pengujian tanaman teh dapat dibudidayakan dan tumbuh di daerah tropis dengan ketinggian 2002000 meter di atas permukaan laut. Temperatur yang di kehendaki tanaman teh adalah $14-25^{\circ} \mathrm{C}$ (Kusnaedi, 2009).

Harga yang cukup teerjangkau membuat minuman es teh diolah oleh produsen dengan cara yang kurang baik (higines) ada beberapa kasus terjadinya diare setelah mengkonsumsi es teh, namun tidak dimasukkan dalam media karena merupakan penyakit yang tidak berbahaya. Namun hal ini tidak bisa dibiarkan serta merta begitu saja harus ada tindakan nyata yang dilakukan agar kasus diare akibat mengkonsumsi es teh dapat diminimalisir. Salah satunya adalah dengan melakukan uji coba adanya bakteri yang ada pada minuman es teh, yang dalam hal ini adalah dari jenis E. Coli.

Escherichia coli merupakan flora normal di dalam usus manusia dan akan menimbulkan penyakit bila masuk kedalam organ atau jaringan lain. Esherichia coli merupakan penyebab utama meningitis dan penyebab infeksi tractus urinarius (Pyelonephiritis, Crystisis). Jenis tertentu dari Esherichia coli dapat menyebabkan penyakit diare. Bakteri Esherichia coli ini sering menimbulkan wabah diare (Entjang, 2003). Terdapat beberapa faktor penyebab masuknya bakteri ini pada manusia salah satunya adalah konsumsi minuman secara langsung yang dalam penelitian ini yang kita tinjau adalah minuman es teh. Faktor-faktor kontaminasi minuman es teh dapat disebabkan dari air cucian gelas yang kotor, air putih yang ditambahkan kedalam teh tidak diketahui secara pasti tingkat kematangannya, gelas yang digunakan tidak bersih atau belum kering setelah proses pencucian, alat yang dipakai untuk membersihkan gelas, proses pembuatan dan penjual 
minuman es teh yang kurang memperhatikan higienitas dan lingkungan penjualan (Maulida, 2015).

Penelitian terdahulu yang dilakukan oleh Mayang, 2017 disimpulkan bahwa minuman es teh yang dijual di dusun Candimulya Jombang, didapatkan hasil 5 sampel positif terkontaminasi bakteri Escherichia coli dengan indeks MPN 25-1800 sel/100ml dengan persentase $100 \%$ tidak layak konsumsi dengan bakteri kontaminan yaitu Escherichia coli, serta bakteri lain yang diduga Salmonella. Menurut Peratutan Menteri Kesehatan Nomor 492 /Menkes /Per/I V/2010

Tentang Persyaratan Kualitas Air Minum, yaitu parameter mikrobiologi untuk total bakteri Escherichia coli jumlah per $100 \mathrm{ml}$ sampel kadar maksimum yang diperbolehkan adalah 0 .

Berdasarkan uraian tersebut maka dilakukan penelitian uji adanya bakteri Escherichia coli pada penjual es teh di sekitar kampus STIKES Borneo Cendekia Medika Pangkalan Bun. Penelitian ini dilakuka karena banyak ditemukan penjual minuman es teh disekitar kampus dan belum adanya penelitian yang dilakukan untuk menguji adanya bakteri tersebut pada minuman es teh.

\section{METODE PENELITIAN}

Alat

Alat yang digunakan dalam penelitian yaitu: autoklaf, Laminar air flow, rotary evaporatory (Stuart), hot plate (Stuart), tabung reaksi, rak tabung reaksi, tabung durham, pipet ukur, neraca digital, hotplate, batang pengaduk, autoclave, kapas, alumunium foil, Incubator, Bunsen, label, ose jarum, ose bulat, cawan petri dan objek glass.

\section{Bahan}

Bahan yang digunakan dalam penelitian ini yaitu sampel minuman teh, Media Lactose Broth (LB), Media BGLB (Briliant Green Lactose Bile Broth), Media Eosin MethyleneBlue (EMB), Triple Sugar Iron Agar (TSIA),Aquadest dan Pewarna Gram.

\section{Rancangan Penelitian}

Rancangan penelitian yang digunakan dalam penelitian ini adalah deskriptif. Penelitian deskriptif adalah suatu metode yang dilakukan untuk 
mendiskripsikan, menjelaskan, mene mukan dan memaparkan sesuatu yang diteliti. Peneliti menggunakan desain penelitian deskriptif yang merupakan penelitian untuk mengetahui jumlah bakteri Escherichia coli pada minuman es teh yang dijual di sekitar Stikes Borneo Cendekia Medika Pangkalan Bun

\section{Cara Kerja}

\section{Uji Pendugaan (Presumtive Test)}

$\rightarrow$ Mengambil dengan pipet steril 5 x $10 \mathrm{ml}$ air sample, kemudiann masing-masing dimasukkan kedalam tabung berisi $10 \mathrm{ml}$ lactose broth.

$\rightarrow$ Dengan cara yang sama : a) Mengambil 5 x $1 \mathrm{ml}$ air sample, masing-masing di masukkan kedalam 5 tabung berisi $5 \mathrm{ml}$ lactose broth. b) Mengambil $5 \mathrm{x}$ $0,1 \mathrm{ml}$ air sample, masingmasing di masukkan kedalam 5 tabung berisi $5 \mathrm{ml}$ lactose broth.

$\rightarrow$ Semua tabung dieramkan pada suhu 370C selama 18-24 jam.

\section{Uji Penegas (Confirmative test)}

$\rightarrow$ Menyiapkan tabung media BGLB (Briliant Green Lactose Bile Broth) pada pemeriksaan MPN Esherichia coli sesuai tabung yang positif gas pada pemeriksaan presumptive test.

$\rightarrow$ Dari tiap tabung yang positif pada media LB (Lactose Broth) diambil dengan menggunakan ose, kemudian memindahnya kedalam tabung BGLB (Briliant Green Lactose Bile Broth)

$\rightarrow$ Menginkubasi media BGLB (Briliant Green Lactose Bile Broth)pada suhu $37^{\circ} \mathrm{C}$ selama 24 -48 jam.

$\rightarrow$ Melakukan pembacaan yaitu dengan melihat jumlah tabung BGLB (Briliant Green Lactose Bile Broth) yang menunjukkan kekeruhan dan positif gas. 5 . Mencocokkan hasil tabung yang positif dengan tabel MPN.

\section{Uji Pelengkap (Complete test)}

$\rightarrow$ Dari tiap tabung yang positif pada media BGLB, melanjutkan dengan melakukan streak pada media EMB.

$\rightarrow$ Menginkubasi pada suhu $37^{\circ} \mathrm{C}$ selama 24 jam.

$\rightarrow$ Mengamati pertumbuhan koloni dan melanjutkan pada media TSI 
menggunakan ose jarum, menanam pada media TSI

$\rightarrow$ Menginkubasi pada suhu $37^{\circ} \mathrm{C}$ selama 24 jam. 4. Mengamati pertumbuhan pada media TSI.

\section{Waktu dan Tempat}

Penelitian ini dilaksanakan di bulan Februari - April 2019 di Laboratorium Mikrobiologi Program studi D-III Analis Kesehatan STIKES Borneo Cendekia Medika Pangkalan Bun.

\section{HASIL DAN PEMBAHASAN}

Identifikasi jumlah bakteri Escherichia coli pada minuman es teh yang dijual di sekitar kampus STIKES Borneo Cendekia Medika Pangkalan Bun dengan

\begin{tabular}{|l|l|l|l|}
\hline Sampel & $\begin{array}{l}\text { Total } \\
\text { sampe }\end{array}$ & \multicolumn{2}{|c|}{$\begin{array}{c}\text { Hasil } \\
\text { pemeriksaan }\end{array}$} \\
\cline { 3 - 4 } & 1 & positif & $\begin{array}{c}\text { Negati } \\
\mathrm{f}\end{array}$ \\
\hline Kangkun & 30 & 4 & 26 \\
\cline { 3 - 4 } g & & $\begin{array}{l}13,33 \\
\%\end{array}$ & $\begin{array}{l}86,67 \\
\%\end{array}$ \\
\hline
\end{tabular}

\begin{tabular}{|l|c|c|c|c|}
\hline N & Samp & \multicolumn{3}{|c|}{ Hasil Uji } \\
\cline { 3 - 5 } o. & el & Pend & Pene & Peleng \\
& Minu & uga & gas & kap \\
& man & & & \\
Es & & & \\
Teh & & & \\
\hline
\end{tabular}

\begin{tabular}{|c|c|c|c|c|}
\hline 1 & S1 & V & V & V \\
\hline 2 & S2 & V & V & V \\
\hline 3 & S3 & V & V & - \\
\hline 4 & S4 & V & V & V \\
\hline 5 & S5 & V & V & V \\
\hline 6 & S6 & V & V & - \\
\hline 7 & S7 & V & V & V \\
\hline 8 & S8 & V & V & V \\
\hline 9 & S9 & V & V & V \\
\hline 1 & S10 & V & V & - \\
0 & & & & \\
\hline
\end{tabular}

Tabel 4.1 Hasil Identifikasi Jumlah Bakteri Escherichia coli pada Minuman Es Teh yang dijual di STIKES Borneo Cendekia Medika Pangkalan Bun

\section{Keterangan :}

Positif : V Negatif : -

Berdasarkan hasil identifikasi jumlah bakteri Escherichia coli pada minuman es teh yang dijual di STIKES Borneo Cendekia Medika Pangkalan Bun didapatkan hasil semua minuman tidak layak konsumsi dengan persentase $100 \%$.

\section{PEMBAHASAN}

Berdasarkan Tabel 4.1 hasil identifikasi jumlah bakteri Escherichia coli pada minuman teh yang dijual di di sekitar kampus STIKES Borneo Cendekia Medika Pangkalan Bun menggunakan metode MPN dengan 5 seri, tabung ke 10 sampel minuman teh memiliki nilai indeks MPN berkisar antara 25-1800 sel/ 100ml. Sampel 
yang menandakan sampel minuman teh tersebut tidak layak untuk dikonsumsi dengan bakteri kontaminan yaitu sampel 1, sampai 9 terkontaminasi bakteri Eschericia coli, dan pada sampel 5 dan 10 terkontaminasi bakteri lain yang diduga Salmonella sp. Kehadiran bakteri kolon didalam suatu contoh air menunjukkan adanya cemaran yang berasal dari kotoran manusia atau hewan dan hal ini dianggap identik dengan adanya bakteri pathogen (Dwidjoseputro ,2005).

Menurut Peraturan Menteri Kesehatan Republik Indonesia Nomor 492/Menkes/Per/IV/2010 Tentang Persyaratan Kualitas Air Minum, yaitu parameter mikrobiologi untuk bakteri Eschericia coli jumlah per $100 \mathrm{ml}$ sampel kadar maksimum yang diperbolehkan adalah $0 . \quad$ Dari pengamatan peneliti yang dilakukan tingginya persentase tidak layak untuk di konsumsi pada minuman teh bisa dipengaruhi oleh faktor-faktor kontaminasi yaitu cara penyeduhan teh, penambahan es balok, air putih, penggunaan gelas, tidak memperhatikan higienitas. Dari lingkungan. Adanya bakteri lain seperti Salmonella sp bisa terjadi karena terkontaminasi dari tempat pencucian, sendok dan alat-alat lainnya, dan diduga terkontaminasi dari udara sekitar terutama dari debu, selain itu juga karena penjual tidak memperhatikan higienitas terutama mencuci tangannya dan dari lalat yang sudah terinfeksi bakteri Salmonella sp dan mengontaminasi ke bahan atau alat yang digunakan oleh penjual.

Cara penyeduhan teh yang tidak menggunkan air yang benar-benar mendidih dan dibiarkan sepanjang hari tanpa di tutup sehingga bakteri masuk melewati udara. Bakteri Escherichia coli dapat mati pada suhu $60^{\circ} \mathrm{C}$ selama 30 menit dan pada suhu diatas $100^{\circ} \mathrm{C}$ selama 10 menit, tetapi ada juga yang resisten (Parahita, 2009). Dengan penambahan es balok yang diduga berbahan dasar air mentah yang mengandung bakteri Escherichia coli. Dimana beberapa bakteri Escherichia coli dapat bertahan hidup dalam es selama 6 bulan. Selain dari bahan dasar es balok bakteri juga dapat masuk melalu tempat es batu yang tidak bersih (Parahita , 2009). Dari air putih yang di perkirakan berasal dari air isi ulang yang diduga mengandung bakteri Escherichia coli. Dimana tempat airnya (galon) sama tidak di ganti, saat 
mengisi air isi ulang tidak menutup sehingga bakteri dapat mengontaminasi melalui udara, tempat air (galon) dan pemompa airnya pada saat digunkakan tidak disterilkan terlebih dahulu.

Penggunaan gelas dimana air pencucian gelas yang digunakan untuk beberapa kali sehingga air kotor dan dapat menyebabkan kontaminasi bakteri. Penjual juga tidak memperhatikan higenitas seperti mengambil es batu tidak menggunakan alat tetapi menggunakan tangan dimana tngan penjual kotor dan tidak di mencuci tangan. Penambahan es batu balok pada minuman es teh mempengaruhi kontaminasi bakteri Escherichia coli yang telah ditunjukan oleh penelitian sebelumnya menyatakan didapatkan hasil penelitian menunjukan bahwa $88,9 \%$ sampel es batu rumah tangga yang digunakan tidak memenuhi syarat di karena terkontaminasi bakteri dengan salah satu bakterinya adalah Escherichia coli (Semiarti, 2014). Penambahan air putih yang berasal dari air isi ulang yang diduga mengandung bakteri Escherichia coli yang telah ditunjukkan oleh penelitian sebelumnya yang menyatakan bahwa hasil penelitian dari 9 sampel hanya 1 yang layak minum sementara 8 sampel lainya tidak layak konsumsi minum. Dari 8 sampel tersebut, 5 sampel positif bakteri Escherichia coli sementara 3 sampel mengandung bakteri coliform (Raharja , 2015).

Untuk higienitas pembuatan es teh juga mempengaruhi terkontaminasi bakteri Escherichia coli yang telah ditunjukkan oleh penelitian sebelumnya berdasarkan hasil penelitian seluruh sampel es teh mengandung bakteri Escherichia coli (Chahaya,2013). Sumber kontaminasi mikroorganisme dapat berasal dari air, udara, peralatan serta manusia. Dimana kualitas air akan berpengaruh sangat besar terhadap kualitas mikroba pangan. Jenis bakteri di udara didominasi bakteri berbentuk batang Gram negatif. Selama proses produksi dan konsumsi pangan akan bersentuhan dengan berbagai orang yang menangani pangan yang menjadi sumber kontaminasi mikroorganisme patogen yang selanjutnya menyebabkan penyakit bawaan pangan serta penggunaan peralatan yang terus menerus dalam jangka waktu lama, mikroorganisme awal akan berkembang biak dan terus menerus 
menjadi sumber kontaminasi dalam produk (Sopandi dan Wardah , 2014, 43). Mikroorganisme yang paling umum digunakan sebagai petunjuk atau indikator adanya cemaran feces dalam air adalah Eschericia coli serta bakteri dari kelompok coliform. Bakteri dari jenis tersebut selalu terdapat di dalam kotoran manusia, sedangkan bakteri patogen (penyebab penyakit) tidak selalu ditemukan. Mikroorganisme dari kelompok Coliform secara keseluruhan tidak umum hidup atau terdapat di dalam air, sehingga keberadaannya dalam air dapat dianggap sebagai petunjuk terjadinya pencemaran kotoran dalam arti luas, baik dari kotoran hewan maupun manusia. Bakteri kelompok coliform meliputi semua bakteri berbentuk batang, Gram negatif, dan dapat menfermentasi laktosa dengan memproduksi gas dan asam pada suhu 370C dalam waktu kurang dari 48 jam (Purnawijayanti, 2006). Menurut Brook, (Butel dan Morse ， 2005, 359) Kontaminasi produk makanan oleh sampah yang mengandung Escherichia coli yang menyebabkan diare merupakan cara penyebaran bakteri. Keberadaan Salmonella sp. dapat menyebabkan gastroenteritis yang ringan sampai dengan demam tifoid yang berat di sertai bakteremia.

\section{KESIMPULAN}

Dari hasil penelitian yang dilakukan dapat disimpulkan bahwa minuman es teh yang dijual di sekitar kampus STIKES Borneo Cendekia Medika Pangkalan Bun didapatkan hasil 10 sampel positif terkontaminasi bakteri Escherichia coli dengan indeks MPN 25-1800 sel/100ml.

\section{SARAN}

Persentase $100 \%$ tidak layak konsumsi dengan bakteri kontaminan yaitu Escherichia coli, serta bakteri lain yang diduga Salmonella.

\section{DAFTAR PUSTAKA}

Iskamto, B. 2009. Bakteriologi Kesehatan. UNS Press, Surakarta.

Waluyo, L. 2005. Mikrobiologi Lingkungan. UMM Press, Malang.

Ariefiansyah, Netti suharti, Eliza Anas, 2015.Identifikasi Bakteri Coliform yang Terdapat pada Minuman Es Teh Di Rumah Makan Tepi Laut Purus Padang Barat.

Brook, Geo F, Janet S. Butel, Stephen A. Morse 2005, Mikrobiologi Kedokteran, Salemba Medika, Jakarta.

Cahaya, 2013. Analisi Escherichia coli Dan Higiene sanitasis Pada Minuman Es Teh yang Dijual Di Pajak Karona Jamin Ginting Kecamatan Medan Baru. 
Dian Maulida Widyan, 2015. Sopandi, T \& Wardah, 2014. Perhitungan Jumlah Bakteri Coliform pada Minuman Es Teh yang Dijual Di Warung Makan Mikrobiologi Pangan. Andi. Yogyakarta Sekitar Pasar Legi Citra Niaga Jombang.

Entjang, 2003. Mikrobiologi dan Parasitologi Untuk Akademi Keprawatan Dan Sekolah Tenang Kesehatan Yang Sederajat. Citra Aditya Bakti. Bandung.

Kusnaedi, 2009.TerapiTeh Cara Ampuh dan Mudah Mencegah dan Mengobati Kolesterol, Diabetes, Darah Tinggi, Kanker, Sariawan, Sakit Perut, Sakit gigi dan Flu. Duta Media Tama. Jakarta.

Parahita, 2009.Isolasi Dan Identifikasi Escherichia coli Dan Staphylococcus aureus Pada Uang Kertas Yang Beredar Di Daerah Sekitar Pasar Sederhana Bandung.

Permenkes RI No. 492/MenKes/Per/IV/2010, Tentang Persyaratan Kualitas Air Minum, Menkes RI, Jakarta.(http://pppl.depkes.go.id /_as set/_regulasi/53_ Permenkes\%20492.pdf)

Purnawijayanti, Hiasinta A 2006, Sanitasi hygiene dan keselamatan kerja dalam pengolahan makanan, Kanisius, Yogyakarta.

Raharja, 2015. Identifikasi Escherichia coli Pada Air Isi Ulang Dari Depot Dikelurahan Pisangan Dan Cirendeu.

Semiarti, 2014. Uji Bakteriologi Es Batu Rumah Tangga Yang Digunakan

Penjual Minuman Di Pasar Lubuk Buaya Kota Padang. 